\title{
Metode Eksperimental Struktur Kolom Beton Bertulang Tahan Gempa Menggunakan CFRP Sebagai Eksternal Confinement
}

\author{
Karmila Achmad ${ }^{1}$, Agoes SMD ${ }^{2}$ dan Tavio ${ }^{3}$ \\ 1. Jurusan Teknik Sipil Politeknik Negeri Balikpapan, Balikpapan \\ 2. Jurusan Teknik Sipil Struktur Universitas Brawijaya, Malang \\ 3. Jurusan Teknik Sipil dan Perencanaan-FTSP Institut Teknologi Sepuluh Nopember, Surabaya \\ Email : milabpp@yahoo.co.id
}

\begin{abstract}
This paper analyzes about the increasing of the strength by seismic load in RC square column structure which has been given CFRP external confinement. There are two specimens will be compared. They are C-1and $C-1 C . C-1$ is control column and C-1C is column with CFRP external confinement. Analysis experimental result got that collapse $C-1$ column at plastic hinge zone and collapse $C-1 C$ column until the end of the test the demage of column surface from all of plastic hinge zone. They are effected by the concrete demage and colour of the resin CFRP changing and the increasing displacement 77\% from the plan. From 3 strength parameters, show that $C-1 C$ increases its strength for $P_{\max }$ increase $54,97 \%, \delta_{\max }$ is $81,18 \%$ and $M_{\max }$ is $55,36 \%$ for $C$ - 1 .
\end{abstract}

Keywords- Seismic load, CFRP, RC column, Experimental method, External confinement,

\begin{abstract}
Abstrak
Makalah ini meneliti mengenai peningkatan kekuatan dengan adanya beban gempa yang bekerja pada elemen struktur kolom beton bertulang pada bangunan tinggi yang telah diberi pengekangan eksternal CFRP. Ada dua benda uji yang akan dibandingkan yaitu C-1 sebagai kolom control dan C-1C sebagai kolom dengan pengekangan CFRP. Dari hasil eksperimental kegagalan kolom C-1 terjadi pada zona sendi plastis dan C-1C sampai akhir pengujian permukaan kolom pada zona sendi plastis secara keseluruhan sudah tidak rata akibat rusak beton dibagian dalam dan perubahan warna resin CFRP serta terjadi peningkatan displacement $77 \%$ dari displacement rencana. Dari 3 parameter kekuatan menunjukan bahwa C-1C memiliki kekuatan meningkat dengan rincian $P_{\max }$ meningkat 54,97\%, $\delta_{\max }$ meningkat 81,18\% dan $M_{\max }$ meningkat 55,36\%.
\end{abstract}

Kata Kunci- Beban gempa, CFRP, Kolom beton bertulang, Metode eksperimental, Pengekangan eksternal

\section{Pendahuluan}

Tren penduduk perkotaan terus mengalami peningkatan yang tercermin pada semua propinsi di Indonsia. Di tahun 2000, persentase penduduk daerah perkotaan sudah mencapai 42 persen. Dan pada tahun 2015 diprediksi prosentase penduduk kota akan menjadi lebih besar dibandingkan desa yaitu $56 \%$. Dengan pertumbuhan penduduk kota yang melampaui kapasitas dari lahan kota akan berakibat pada pertumbuhan kota yang vertikal (uper ground). Baik berupa pertumbuhan ke atas (overground space) maupun kebawah (underground space).
Untuk Indonesia saat ini pertumbuhan kota lebih mengarah pada overground space, ini terbukti dengan banyaknya bangunan tinggi dan bermunculan gedung pencakar langit. Namun tanpa disadari pertumbuhan kota keatas adalah sangat rawan terhadap bahaya gempa bumi. Sehingga perlu dilakukan antisipasi terhadap gedung-gedung tinggi dengan memberikan inovasi material sebagai perkuatan struktur bangunan tinggi agar didapatkan peningkatan kekuatan struktur sehingga aman dari bahaya gempa. 


\section{Tinjauan Pustaka}

\section{Fenomena Gempa Bumi}

Kondisi overground space menimbulkan resiko yang tinggi atas bahaya gempa bumi. Sehingga perilaku gempa (jalur seismic, titik pusat gempa, serta kecenderungan pergeseran kulit bumi), secara makro harus dipahami untuk kepentingan meminimalisir dampak kerusakan bangunan dan kota akibat terjadinya gempa. Beberapa kasus bencana gempa bumi di perkotaan korban jiwa terbesar justru diakibatkan oleh efek sekunder (secondary effect) yaitu terjadinya "keruntuhan" bangunan pasca guncangan gempa, serta karena kebakaran sebagai efek sampingnya. Efek sekunder terjadi karena adanya gerakan susulan yang dapat mencapai pada wilayah yang lebih luas, yang menyebabkan kerusakan yang relatif besar.

Kerawanan bencana gempa di Indonesia secara geologis memiliki potensi yang besar, khususnya pada beberapa bagian wilayah dan kota yang berada pada jalur yang dilalui patahan lempeng (tectonic) Eurasian (Asia, pasifik dan Australia) dan garis circumstance, "Pacific-rims: ring of fire" yaitu garis potensi bencana gunung berapi (volcanic) yang membentang di sepanjang Asia, Pasifik, dan Amerika yang melewati wilayah Indonesia. Adanya hasil revisi peta gempa Indonesia menunjukan bahwa telah terjadi peningkatan zona gempa untuk beberapa wilayah di Indonesia. Dan korban gempa bumi terbesar (75\% lebih) terjadi di wilayah perkotaan. ${ }^{19}$

\section{Kekuatan Struktur Gedung Tinggi}

Dengan banyaknya penduduk kota akan berakibat pada pertumbuhan kota vertikal ke atas. Disisi lain pada struktur gedung tinggi adalah rawan terhadap bahaya gempa bumi. Terutama untuk wilayah Indonesia yang mengalami peningkatan zona gempa. ${ }^{18}$ Kekuatan struktur erat kaitannya dengan adanya peningkatan beban secara tiba-tiba (beban gempa) yang melampaui desain awal

Kolom memegang peranan penting dalam struktur gedung, mengingat kegagalan kolom akan mengakibatkan kegagalan (collapse) struktur secara keseluruhan. Disisi lain, kolom adalah elemen struktur yang rentan terhadap kegagalan ketika menerima beban gempa. ${ }^{11}$ Dalam penelitian ini beban gempa direpresentatifkan dengan beban siklik.

\section{Kolom Penampang Persegi}

Perilaku pengekangan eksternal untuk kolom persegi berbeda dibanding kolom bulat. Pada kolom persegi efektifitas pengekangan akan jauh berkurang jika dibandingkan dengan kolom bulat. ${ }^{7}$

Pada gambar 1 menunjukkan bentuk dari bagian yang terkekang untuk dimensi $B \times H$ dan jari-jari sudut $r$. Daerah tidak terkekang umumnya diwakili oleh empat parabola (fungsi kuadrat) dengan kemiringan awal adalah 45 derajat.

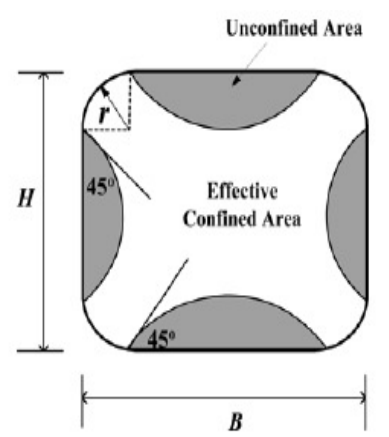

Gambar 1: Gaya kekang pada penampang persegi

\section{Carbon Fiber Reinforced Polymer (CFRP)}

Serat karbon didefinisikan sebagai serat yang mengandung setidaknya $90 \%$ berat karbon. Digunakan fiber graphite yang merupakan serat dengan karbon diatas $95 \%$ beratnya. Yang paling umum digunakan adalah poliakrilonitril (PAN), (petroleum) minyak bumi, serat selulosa (Viscose rayon, katun) dan fiber phenolic tertentu. Tidak seperti serat kaca dan aramid, serat karbon tidak menunjukkan korosi atau pecah pada suhu kamar.

\section{Metoda Penelitian Spesimen}

Jumlah spesimen sebanyak 2 (dua) buah kolom beton bertulang $\mathrm{C}-1$ dan $\mathrm{C}-1 \mathrm{C}$ yang 
identik dengan tinggi efektif $1100 \mathrm{~mm}$ dan penampang 350 x $350 \mathrm{~mm}$. Spesimen menggunakan tulangan longitudinal 8D19 dan tulangan transversal Ø10-200. C-1 adalah kolom original sebagai kolom control yang merupakan kolom beton bertulang tanpa perkuatan eksternal CFRP dan C-1C adalah spesimen kolom perkuatan dengan pengekangan CFRP 1 lapis.

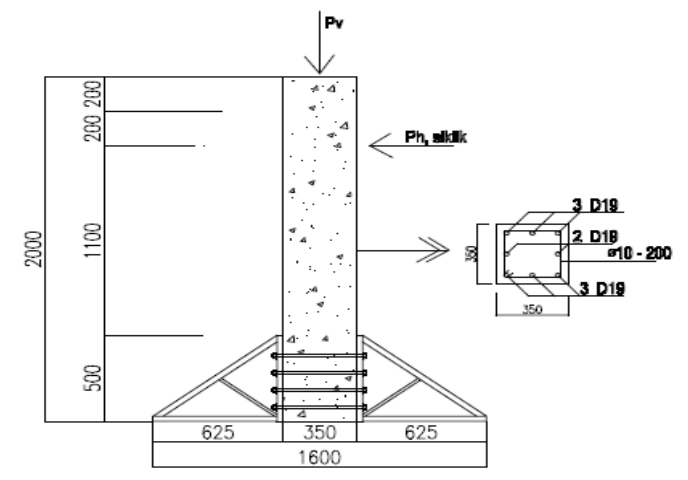

(a)

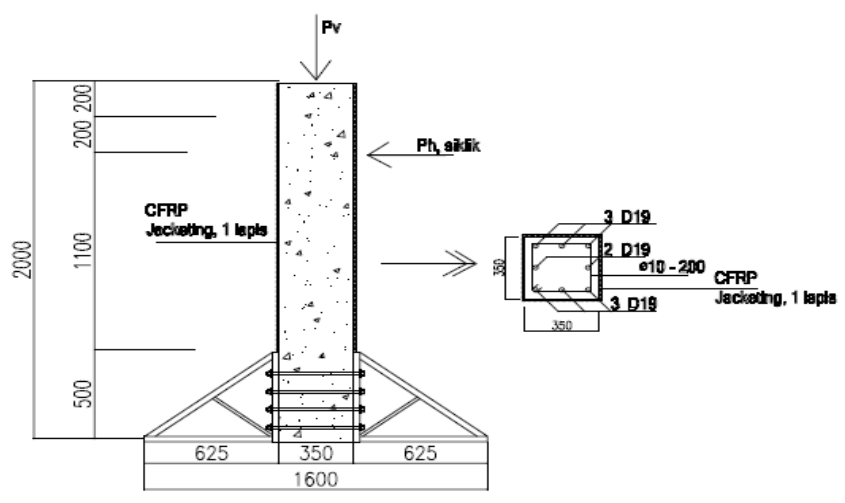

(b)

Gambar 2: Spesimen kolom (a) C-1 dan (b) C-1C

\section{Instrumentasi}

Dalam penelitian ini akan menggunakan strain gauge tulangan baja FLA-6-11 dan train gauge fiber BFLA-5-8. Untuk masingmasing spesimen, Strain gauge FLA-6-11 dipasang pada tulangan longitudinal sebanyak 4 buah, pada 2 lapis sengkang sebanyak 4 buah dan 2 buah strain gauge BFLA-5-8 dipasang pada CFRP.
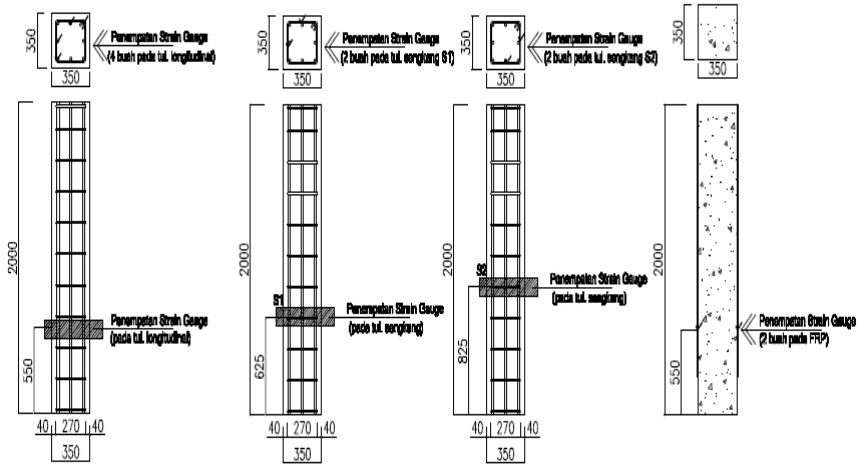

(a) (b-1)

(b-2)

(c)

Gambar 3: Penempatan strain gauge (a) tulangan longitudinal, (b-1) (b-2) sengkang dan (c) Fiber

\section{Set-up Pengujian}

Pelaksanaan pengujian disesuaikan dengan peralatan yang tersedia di Laboratorium Puslitbang Teknologi Permukiman Departemen Permukiman dan Prasarana Wilayah, Bandung. Spesimen kolom yang diuji diposisikan berdiri tegak pada 2 buah rangka baja (loading frame) yang diletakkan di atas lantai kerja yang dikunci pada ujung-ujungnya balok tumpuan dengan mur, yang secara skematik ditunjukkan dalam Gambar 4. 


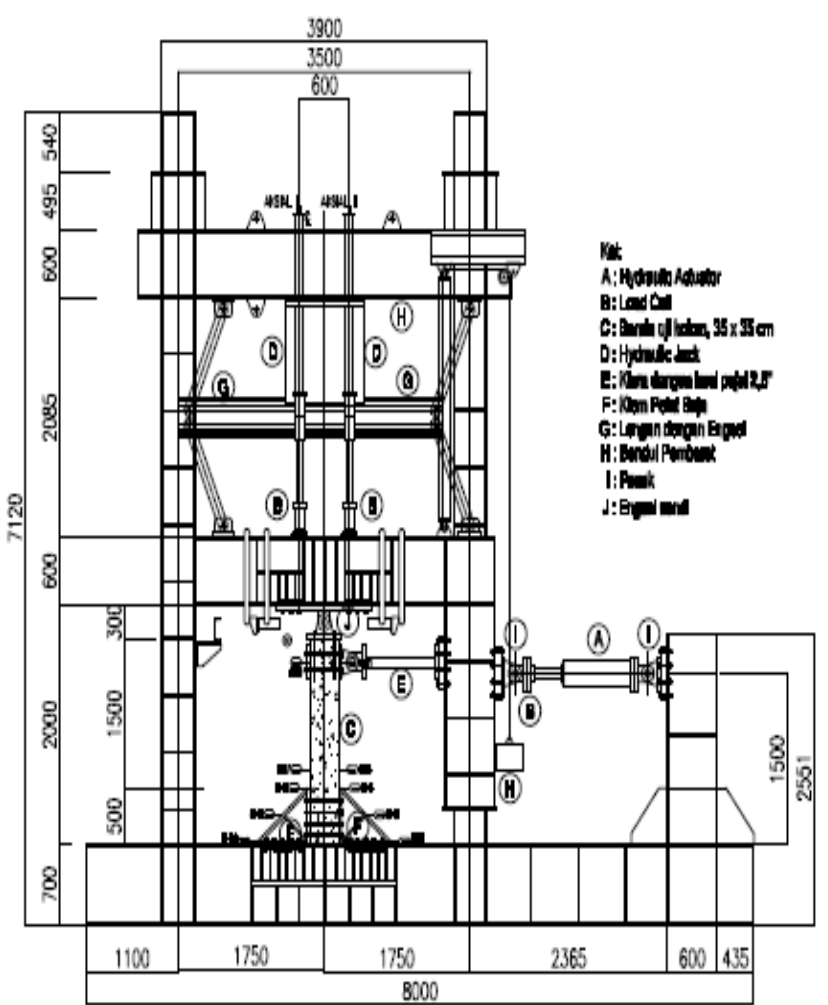

\section{Gambar 4. Set-up pengujian kolom} Aplikasi CFRP

Aplikasi CFRP dengan metode wet layup dengan pemasangan full jacketing arah serat horisontal dan overlap $200 \mathrm{~mm}$. FRP dipasang 1 lapis kecuali pada kepala kolom setinggi $775 \mathrm{~mm}$ dipasang 3 lapis dengan tujuan untuk menghindari kegagalan pada kepala kolom. Aplikasi CFRP pada specimen $\mathrm{C}-1 \mathrm{C}$ dilakukan setelah beton kering dan sebelum pengujian siklik.

\section{Beban Rencana}

Besar beban aksial yang bekerja adalah konstan dan dilakukan variasi untuk beban siklik. Berdasarkan hasil analisa awal, dengan mengasumsikan kolom yang diuji adalah kolom pada lantai tengah gedung bertingkat maka beban aksial yang bekerja sebesar 30\% dari kapasitas original column yaitu 748 kN. Sedangkan besarnya beban lateral yang bekerja pada masing-masing specimen adalah $181,57 \mathrm{kN}$ untuk C-1 dan $225,95 \mathrm{kN}$ untuk C-1C.

\section{Hasil dan Pembahasan Kegagalan Specimen C-1}

Retak awal yang terjadi pada kolom original berupa retak lentur pada zona sendi plastis. Retak ini searah dengan tulangan transversal pada rasio lateral drift 0,25\% dengan beban 78,2 $\mathrm{kN}$. Panjang retak rambut sekitar $7 \mathrm{~cm}$ dengan lebar retak berkisar 0,01 s.d $0,02 \mathrm{~mm}$. Pola pertambahan retak bersifat merambat keatas tinggi kolom.

Dengan meningkatnya beban maka pada specimen C-1 terjadi retak geser yang berkembang dengan cepat dan menyebar disemua sisi kolom. Perkembangan retak geser ini mengakibatkan retak yang terbentuk pada kedua sisi kolom bergabung menjadi satu yang nantinya mengakibatkan spalling pada sisi tekan pada kolom C-1 yang menyebabkan tulangan longitudinal terlihat dengan jelas.

Sedangkan leleh baja longitudinal pada rasio lateral drift $0,75 \%$ siklus pertama pada beban $149,5 \mathrm{kN}$. $\mathrm{P}_{\max }$ tercapai pada rasio lateral drift $2,75 \%$ siklus pertama dengan nilai $278,9 \mathrm{kN}$. Kegagalan specimen C-1 ditampilkan pada gambar 5 .

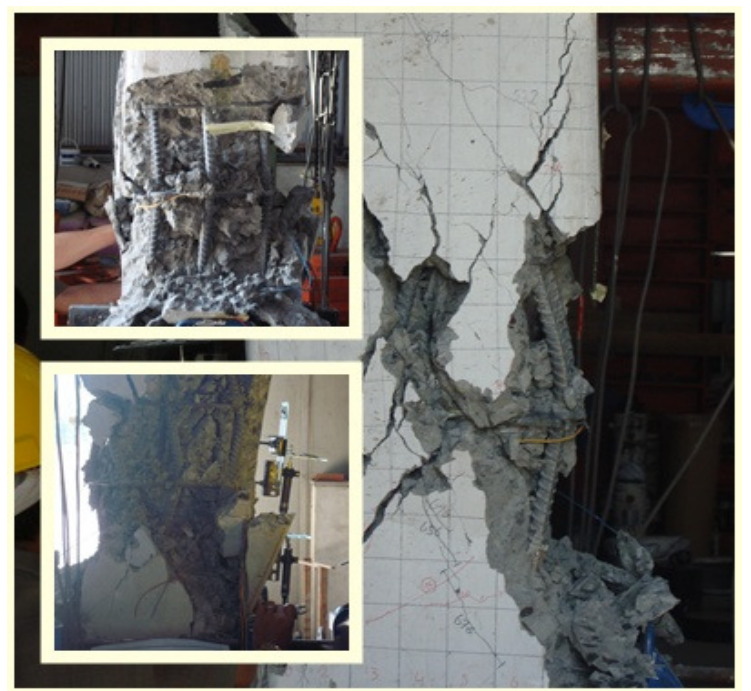

Gambar 5. Kegagalan specimen $\mathrm{C}-1$ 


\section{Kegagalan C-1C}

Kegagalan specimen C-1C ditandai dengan perubahan warna resin pada FRP dan rusaknya permukaan beton daerah sendi plastis. Leleh tulangan pertama pada rasio lateral drift $0,75 \%$ siklus pertama. Regangan CFRP putus pada rasio lateral drift 2,75\% siklus pertama dengan besar beban lateral adalah $347,5 \mathrm{kN}$.

Dari hasil eksperimental menunjukan bahwa kegagalan FRP didahului dengan perubahan warna pada resin. Kegagalan dimulai dari beberapa serat di satu lokasi karena terjadi retak beton. Beban puncak terjadi pada rasio lateral drift 5\% siklus pertama dengan nilai beban lateral $432,2 \mathrm{kN}$. Sampai dengan akhir pola pembebanan yang diacu yaitu 5\% siklus ke tiga kondisi ultimate specimen belum tercapai. Sehingga rasio lateral drift ditingkatkan sampai 8,5\% siklus ke tiga dengan kondisi visual kemiringan specimen terlihat dengan jelas dan nilai displacement yang diperoleh adalah $96,46 \mathrm{~mm}$ yang meningkat $77,81 \%$ dari displacement rencana.

Kegagalan yang terjadi sampai akhir pengujian, untuk permukaan kolom pada zona sendi plastis secara keseluruhan sudah tidak rata akibat rusaknya beton dibagian dalam dan perubahan warna resin FRP. Kondisi akhir specimen C-1C ditampilkan pada gambar 6 .
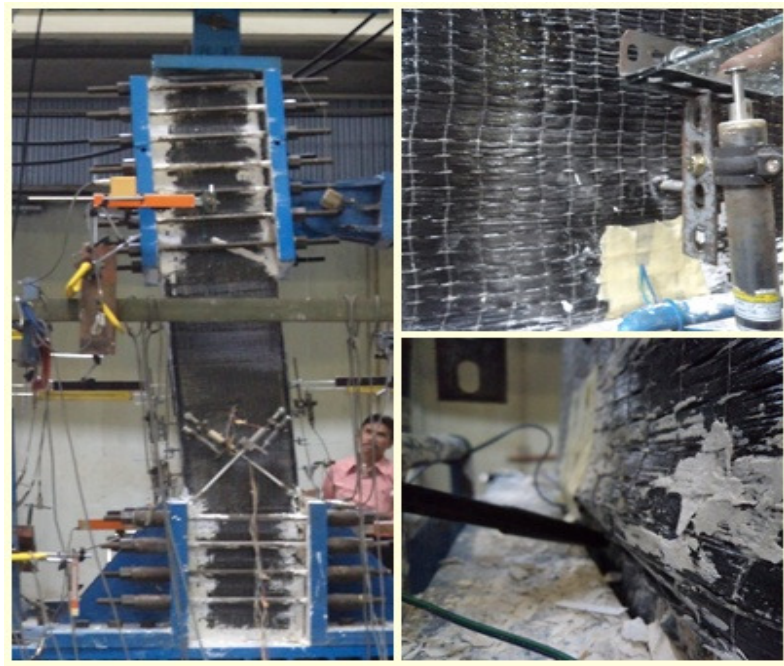

Gambar 6. Kegagalan specimen C-1C

\section{Beban Lateral-Displacement}

Grafik $\mathrm{P}-\boldsymbol{\delta}$ merupakan data yang dibaca dari load cell berupa beban siklik dari LVDT 2 untuk displacement. Dari grafik P- $\delta$ dapat kita tentukan fenomena yang terjadi selama pengujian untuk specimen $\mathrm{C}-1$ dan C-1C. Besarnya $\mathrm{P}_{\max }$ yang terjadi adalah $278,9 \mathrm{kN}$ dan $432,2 \mathrm{kN}$ serta $\delta_{\max }$ yang terjadi adalah $53,24 \mathrm{~mm}$ dan $96,46 \mathrm{~mm}$ untuk C-1 dan C-1C.

Prosentase peningkatan $\mathrm{P}_{\max } \quad \mathrm{C}-1 \mathrm{C}$ terhadap C-1 adalah 54,97\% dan peningkatan $\delta_{\max }$ terhadap $\mathrm{C}-1$ adalah $81,18 \%$. Sehingga prosentase peningkatan kekakuan kolom C-1C terhadap C-1 adalah $55,36 \%$. Grafik beban lateral-displacement ditunjukan pada gambar 7 .

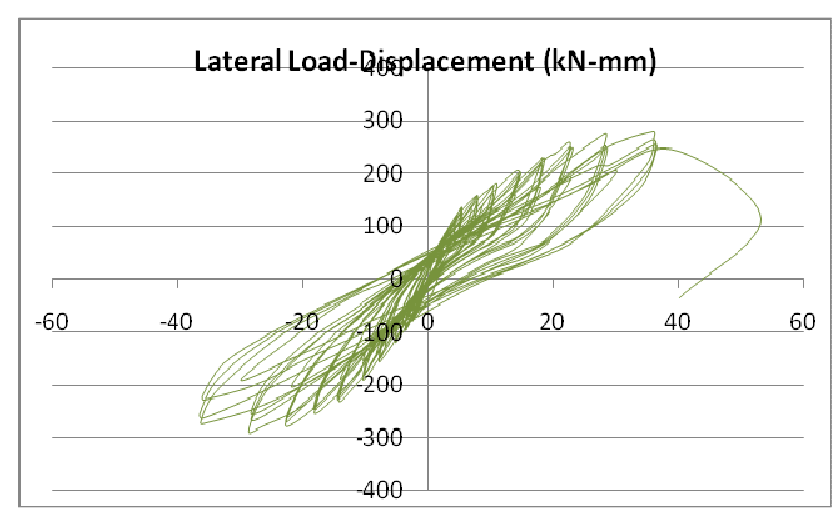

(a)

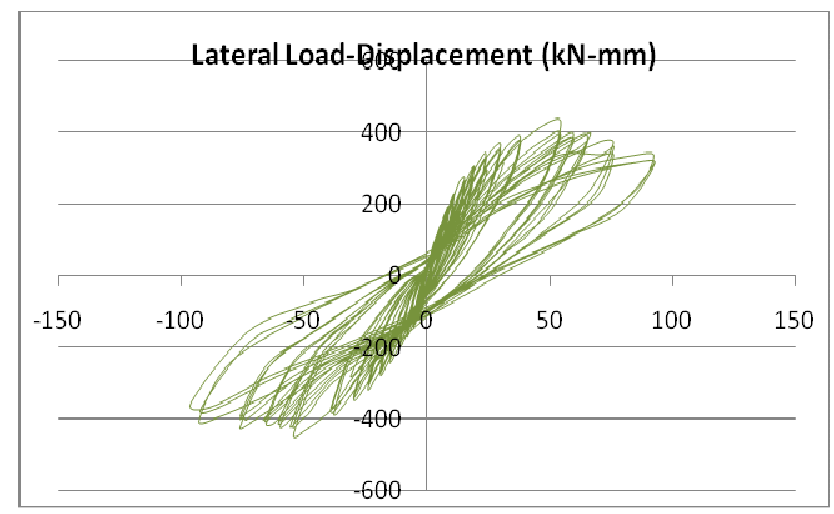

(b)

\section{Gambar 18. Grafik beban latera displacement: (a) C-1 dan} (b) C-1C 


\section{Kesimpulan}

Dari tiga parameter kekuatan yang diukur yaitu $\mathrm{P}_{\max }, \delta_{\max }$ dan $\mathrm{M}_{\max }$, dapat ditarik kesimpulan bahwa terjadi peningkatan kekuatan untuk specimen dengan pengekangan CFRP dibandingkan dengan kolom original.

1. Dari parameter $\mathrm{P}_{\max }$ besar peningkatan C-1C terhadap C-1 adalah 54,97\%

2. Dari parameter $\delta \max$ prosentase peningkatan $\mathrm{C}-1 \mathrm{C}$ terhadap $\mathrm{C}-1$ adalah $81,18 \%$

3. Dari parameter Mmax peningkatan yang terjadi pada $\mathrm{C}-1 \mathrm{C}$ terhadap $\mathrm{C}-1$ adalah $55,36 \%$.

\section{Ucapan Terima Kasih}

Penulis mengucapkan terima kasih kepada FYFE Co. LLC Singapore dengan perwakilan di Indonesia adalah PT. Master Solusi Indonesia (MSI) atas bantuan dan kerjasamanya dalam menyediakan material CFRP (Tyfo ${ }^{\circledR}$ Fibrwrap ${ }^{\circledR}$ Composite Systems) dan applicator-nya.

\section{Daftar Pustaka}

1. ACI 440.2R-02. "Guide for the Design and Construction of Externally Bonded FRP Systems for Strengthening Concrete Structures". ACI Committee 440, 2002

2. ACI 374.1-05. "Acceptance Criteria for Moment Frames Based on Structural Testing and Commentary". ACI Committee 374, 2005

3. Al-Sulayfani, B and Al-Taee, H. "Modeling of Stress-Strain Relationship for Fibrous Concrete Under Cyclic Loads" Eng.Tech.Vol.26, No1, 2008, pp. 4553

4. Bae, S and Bayrak, O. "Seismic Performance of Full-Scale Reinforced Concrete Columns" ACI Structural Journal" March-April, 2008, pp. 123-133

5. Balaguru, P, Nanni, A and Giancaspro, J. "FRP Composites for Reinforced and
Prestressed Concrete Structures" Taylor \& Francis Group, New York, 2009

6. Bank, Lawrence. "Structural Design with FRP Materials" John Wiley \& Sons, INC, Canada, 2006

7. Benzaid, R, Chikh NE and Mesbah H. "Behaviour Of Square Concrete Column Confined With GFRP Composite Warp", Journal Of Civil Engineering And Management, 2008

8. Cole, C. and Belarbi, A. "Confinement Characteristics of Rectangular FRPJacketed RC Columns", Proceedings of the Fifth International Symposium on Fiber Reinforced Polymer for Reinforced Concrete Structures (FRPRCS-5), Cambridge, UK, July 1618, 2001, pp. 823-832.

9. Dhakal, RP and Maekawa, K. "PostPeak Cyclic behavior and Ductility of reinforced Concrete Columns"

10. Faella, A, Napoli, A and Realfonzo, R. "Cyclic Behaviour of Concrete Columns Confined with FRP Systems" Fourth International Conference on FRP Composites in Civil Engineering (CICE2008), 22-24July 2008, Zurich, Switzerland, pp. 1-6

11. Gangarao, $\mathrm{H}$, Taly, $\mathrm{N}$ and Gangarao, $\mathrm{H}$. "Reinforced Concrete Design with FRP Composites" CRC Press, Prancis, 2007

12. Harajli, $\mathrm{M}$ and Dagher, F. "Seismic Strengthening of Bond-Critical Regions in Rectangular Reinforced Concrete Columns Using Fiber-Reinforced Polymer Wraps" ACI Structural Journal, January-February 2008, pp.6877

13. Kumar, ES, Murugesan, $A$ and Thirugnanam, G.S. "Experimental Study on Behavior of Retrofitted with FRP Wrapped RC Beam-Column Exterior Joints Subjected to Cyclic Loading" International Journal of Civil and Structural Engineering, Vol. 1, No.1, 2010, pp.64-79

14. Lee, Chung-Sheng, Hegemier, GA and Philippi DJ. "Analitical Model for Fiber Reinforced Polymer Jacketed Square 
Concrete Columns in Axial Compression" ACI Structural Journal, 2010 pp.208-217

15. Nawy, Edward. "Beton Bertulang Suatu Pendekatan Dasar" PT. Refika Aditama, Bandung, 2008

16. Panitia Teknik Standardisasi Bidang Konstruksi dan Bangunan. "Tata Cara Perhitungan Struktur Beton Untuk Bangunan Gedung (SNI 03-28472002)”. Badan Standardisasi Nasional. Bandung, 2002

17. Park, $\mathrm{R}$ and Paulay,T."Reinforced Concrete Structures" John Wiley and Sons, Canada, 1975

18. Rousakis, $\mathrm{T}$ and Tepfers, R. "Behavior of Concrete Confined by High EModulus Carbon FRP Sheets, Subjected to Monotonic and Cyclic Axial Compressive Load"'

19. Saadatmanesh, H, Ehsani, MR and Li, MW. "Strength and Ductility of Concrete Columns Externally Reinforced with Fiber Composite Straps" ACI Structural Journal, 1994
20. Sheikh, SA and Liu, J. "Enhancing Seismic resistance of Concrete Columns with FRP" Proceedings fib Symposium PRAGUE, 8-10 June 2010

21. Tavio, Purwono, $\mathrm{R}$ dan Rosyidah, A. "Peningkatan Daya Dukung dan Daktilitas Balok Beton Bertulang Dengan Menggunakan Perkuatan CFRP (Carbon Fiber Reinforced Polymer" Dinamika Teknik Sipil, 2009

22. Teng, J. G, Huang, Y. L, Lam, L and Ye L. P. "Theoretical Model for FiberReinforced Polymer-Confined Concrete", Journal of Composites Construction ASCE, March-April 2007, pp.201-210

23. Tim Revisi Peta Gempa Indonesia. "Ringkasan Hasil Studi Tim Revisi Peta Gempa Indonesia 2010" Bandung, 2010

24. Watanabe, K, Niwa, J, Yokota, H and Iwanami, M.

"Stress-Strain Relationship for the Localized Compressive Failure Zone of Concrete under Cyclic Loadin 